\title{
Correction to: Capacity Building: Continuity and Change
}

\author{
Calvin W. L. Ho ${ }^{1}$
}

Published online: 8 February 2020

(C) National University of Singapore and Springer Nature Singapore Pte Ltd. 2020

\section{Correction to: Asian Bioethics Review 11(4): 341-342 https://doi.org/10.1007/s41649-019-00108-z}

Unfortunately, the original version of this article has cited one of its references incorrectly. The in-text citation "Lajaunie and Morand 2018" should have been "Lajaunie and Mazzega 2018", and the correct bibliographic details are:

Lajaunie, Claire, and Pierre Mazzega. 2018. Guest editorial: a pragmatic approach of ethics in interdisciplinary research on biodiversity conservation. Asian Bioethics Review 10 (4): 241-243. https://doi.org/10.1007/s41649-018-0073-9.

The online version of the original article can be found at https://doi.org/10.1007/s41649-019-00108-z

Calvin W. L. Ho

cwlho@hku.hk

1 Centre for Biomedical Ethics (CBmE), Yong Loo Lin School of Medicine, National University of Singapore, Singapore, Singapore 